\title{
The Effect of Brand Image, Brand Love on Brand Commitment and Positive Word-of-Mouth
}

\author{
Tri Cuong DAM ${ }^{1}$
}

Received: August 01, 2020 Revised: September 28, 2020 Accepted: October 05, 2020

\begin{abstract}
This study's purpose was to empirically research the effect of brand image and brand love on brand commitment, and positive word of mouth. We analyzed research data from 267 customers at electronics stores in Ho Chi Minh City, Vietnam. The convenient sampling method was used to collect the research sample. The measurement applied a 5-point Likert scale classifying from 1= completely disagree and 5= completely agree. Based on previous studies, the research model was recommended. The Partial Least Squares method was done to examine the measurement model and the structural model. We had estimated the reliability of the scales through Cronbach's alpha and composite reliability. Besides, we had assessed discriminant validity through the Fornell-Larcker standard. The outcome of the study illustrated that brand image had a significantly positive influence on brand love. Besides, the results of the research declared that brand image was positively related to brand commitment. The results also revealed that brand image was positively linked to positive word of mouth. Likewise, the findings of the study disclosed that brand love had a positive impact on brand commitment and positive word of mouth. Additionally, the results of the research confirmed that brand commitment was positively linked to word of mouth.
\end{abstract}

Keywords: Brand Image, Brand Love, Brand Commitment, Positive Word of Mouth

JEL Classification Code: C38, M30, M31, M37

\section{Introduction}

As a kind of mass communications, word-of-mouth communication has been one of the broadest and the essential means for customers, and it can affect where they buy, what they purchase, and how they assess specific goods and services (Tu et al., 2013). The notion of word of mouth (WOM) has become a necessary term in the marketing activities conducted by multiple companies. Word of mouth has been getting the attention of the social changes and has been identified as one of the most influential and useful communication channels (Sallam, 2014). WOM communication was considered as a vital element of interactive marketing, affecting customers and switching them into spokespersons for the business (Srivastava \&

${ }^{1}$ First Author and Corresponding Author. Lecturer, Faculty of Business Administration, Industrial University of Ho Chi Minh City, Vietnam [Postal Address: 12 Nguyen Van Bao Street, Ward 4, Go Vap District, Ho Chi Minh City, 700000, Vietnam] Email: damtricuong@iuh.edu.vn

(c) Copyright: The Author(s)

This is an Open Access article distributed under the terms of the Creative Commons Attribution Non-Commercial License (https://creativecommons.org/licenses/by-nc/4.0/) which permits unrestricted non-commercial use, distribution, and reproduction in any medium, provided the original work is properly cited.
Sharma, 2017). WOM communication is related to the degree to which a client notifies friends, colleagues, and relationships about products/services that meet their needs (Kazemi et al., 2013). Armelini (2011) revealed that WOM was essentially developed as a marketing tool for two reasons. First, the customers were less concerned with the advertisements in the traditional media. Second, WOM's impact has been improved by a revolution in information and telecommunication technologies that decreases spatial and temporal range amongst individuals (Armelini, 2011).

Some previous studies declared that a positive brand image led to clients' brand love (Islam \& Rahman, 2016; Unal \& Aydin, 2013). Likewise, prior researches revealed that brand image was an antecedent of brand commitment (Maisam \& Mahsa, 2016; Seo \& Park, 2018; Tu et al., 2013) and consumers' positive WOM (Anggraeni \& Rachmanita, 2015; Permana \& Ilham, 2018). Besides, some scholars said that brand love was a predictor of clients' brand commitment (Albert \& Merunka, 2013; Maisam \& Mahsa, 2016) and positive WOM (Bairrada et al., 2019; Hsu \& Chen, 2018). Furthermore, some prior researches declared that brand commitment was a precursor of customers' positive WOM (Maisam \& Mahsa, 2016; Tuškej et al., 2013). However, up to now, little research has investigated the effect of brand 
image, brand love on brand commitment, and positive WOM. Thus, the aim of this research was to empirically research the impact of brand image, and brand love on brand commitment, and positive WOM at electronics stores in Vietnam.

\section{Literature Review and Research Hypotheses}

\subsection{Word of Mouth}

Word of mouth (WOM) was an informal opinion about experiences of product and services exchanged among customers. It was frequently interactive, fast, and lacked commercial inclination. WOM made a substantial impact on consumer behavior. WOM could influence the selection of new brand categories and the choice of brands in developed categories (East et al., 2008). Arndt (1967) revealed that WOM is considered as a spoken person-to-person communication between a receiver and a communicator whom the person recognized as non-commercial, concerning the brand, and its products and services (Arndt, 1967). Stokes \& Lomax (2002) described WOM communication as a personal communication concerning goods/services where the receiver viewed the communicator as unbiased (Stokes \& Lomax, 2002). Word-of-Mouth communication has been seen as a term applied in the marketing and advertising field to try to explain activities that businesses undertake to create individual guidance and recommendation for brand names, goods and services. This kind of communication has essential source credibility because people generally trust someone's view if they knew that it was given willingly and without any request, force, or seeking individual attention while conveying the message (Khraim, 2011). Word of mouth could be recognized as either positive or negative comments made by potential, real or recent consumers about goods/services or business, which was formed possibly through offline or online channels (Hennig-Thurau et al., 2004; Karjaluoto et al., 2016).

Furthermore, other scholars stated that WOM could be positive or negative, and it has occurred traditionally, in offline and individual conversations, or through online communications (Armelini, 2011; Özdemir et al., 2016). Positive word-ofmouth communication was a tool for marketing experts as positive opinions could impact customers to buy the mentioned brand (Arndt, 1967). Contrarily, negative word-of-mouth communication could have the reverse impact. In this opinion, the majority of prior researches have shown that negative wordof-mouth views affect the customers more than the positive ones. (Khraim, 2011; Özdemir et al., 2016). It appeared that negative WOM has a more powerful influence than positive WOM. Thus, when communication was negative, businesses should improve their marketing attempts to offset negative WOM (Arndt, 1967; Bone, 1995). Armelini (2011) stated that marketing attempts to respond toward negative WOM should be concentrated on consumer satisfaction to avoid customers' dissatisfaction, which in turn drives away the negative WOM (Armelini, 2011). File and Prince (1992) affirmed that satisfied clients were likely to have a positive WOM; that was, they will tell others who have not used the goods/services about their satisfaction with the goods/services of a particular brand. Positive WOM has traditionally been considered a benchmark for satisfaction and contributes to an increase in the overall marketplace image of a brand or as a low budget marketing option (File \& Prince, 1991).

\subsection{Brand Image}

Brand image has been an attractive topic of debate in the marketing literature (Cho et al., 2010; Lee \& Lim, 2020; Sousa et al., 2019). Brand image has performed a critical role in distinguishing among businesses and has played a significant role as a powerful marketing tool (H. Park \& Park, 2019). Some researchers have debated if brand image was a crucial part of marketing brands which allowed brands to differentiate their goods/services from their rivals (Aaker, 1996; Kapferer, 1997). The brand image was represented as thoughts about the brand, as was shown by the brand links held in buyer recall (Keller, 1993). The good's image has been seen as the outcome of the communication between the receiver and the goods stimuli. Factors adding to the improvement of the brand image were product characteristics, the business, the marketing mix, the specific thoughts of the brand, individual values, experience, the character of the brand users, and environment variables. Sources of image creation could be either through direct experience of the or through brand communication (Dobni \& Zinkhan, 1990). Brand image has played a crucial role in the decision process of client buying activity. Commonly, a higher brand image showed product quality was beyond a certain level of expectations. But, lower brand image or no brand actually showed clients had no confidence in goods (Hsieh et al., 2018). If a company's goods and services continuously maintained a positive brand image among the community, then it would positively reach a better position in the industry, will have sustainable competitive advantage, and will have a better market share or performance (Park et al., 1986; Sondoh Jr et al., 2007).

Some empirical examinations revealed that brand image was an antecedent of brand love and makes a positive impact on love for the brand (Islam \& Rahman, 2016; Ismail \& Spinelli, 2012). Likewise, prior studies indicated that brand image was a precursor of brand commitment and positively affected brand commitment (Seo \& Park, 2018; Tu et al., 2013). Besides, brand image was a predictor of positive WOM and positively influenced a positive WOM (Anggraeni \& Rachmanita, 2015; Permana \& Ilham, 2018). Therefore, we proposed the following hypotheses.

H1: Brand image is positively related to brand love.

H2: Brand image is positively related to brand commitment.

H3: Brand image is positively related to positive WOM. 


\subsection{Brand Love}

Brand love has been a topic of great concern for brand scholars and managers (Carroll \& Ahuvia, 2006; Ferreira et al., 2019; Sallam, 2014). Consumers can acknowledge a brand as a person; therefore, clients can love a brand as they love a person (Ranjbarian et al., 2013). Carroll and Ahuvia (2006) disclosed that brand love was described as a robust sentimental attachment a satisfied buyer has for a particular trade name. Brand love contained a need for the brand, devotion to the brand, positive evaluation of the brand, positive emotions in reply to the brand, and feelings of love for the brand (Carroll \& Ahuvia, 2006). Meanwhile, Unal and Aydin (2013) stated that brand love was a relatively new topic in marketing literature. Love was a concept we have listened about in our lives. The loving bonds are built with products/services and brands. There have not beenis many studies related to the aspect of brand love, but the scholars who have researched this subject have defined brand love as a powerful link between the customer and the goods which is the same as in interpersonal love (Unal \& Aydın, 2013). Fournier (1998) attracted attention toward the significance of brand love and acknowledged that brand love is like a long term relationship of the consumer with the brand. Other scholars declared that emotional satisfaction was experienced when the pleasure which a customer derives from a product or a brand is converted into love (Dick \& Basu, 1994; Unal \& Aydin, 2013).

Albert and Merunka (2013) revealed that the customers' feelings had a powerful impact on a brand and clients should prefer to sustain this connection (commitment). In consumption circumstances, commitment toward the brand should show some influence (Albert \& Merunka, 2013). Likewise, Dick and Basu (1994) also showed that customers' emotional status concerning a brand influenced their loyalty (Dick \& Basu, 1994). Some empirical studies said that brand love was an antecedent of brand commitment (Albert \& Merunka, 2013; Maisam \& Mahsa, 2016) and positively connected to brand commitment (Albert \& Merunka, 2013). Furthermore, previous researches also stated that brand love was a predictor of positive WOM and made a positive influence on positive WOM (Bairrada et al., 2019; Hsu \& Chen, 2018). Therefore, the following hypotheses were developed.

\section{H4: Brand love has a positive impact on brand commitment. \\ H5: Brand love is positively linked to positive WOM.}

\subsection{Brand Commitment}

Brand commitment was defined as a psychological status of clients which is positively associated with attitudes d rather the brand and there is a readiness to sustain a valued association with it (Albert \& Merunka, 2013; Chaudhuri \& Holbrook, 2001). Brand commitment was also considered as an emotional or psychological attachment to a brand within a product category (Lastovicka \& Gardner, 1979), and this description was based on attitudes rather than based on behaviour (Coulter et al., 2003; Traylor, 1981). Brand commitment and brand loyalty are closely associated but yet they are different (Warrington \& Shim, 2000). Brand loyalty was frequently viewed from a behavioral perspective (Assael, 1988). Brand loyalty was assumed to reflect the repeated purchase of a single brand over a period of time. Though brand commitment indicated brand loyalty; but the opposite was not true. Brand loyalty might reflect merely the customer's need to simplify decision making any buy a product without much thinking. If there is a lack of a preferred brand, brand-loyal customers are likely to make a change to an alternative brand, whereas brand-committed customers will not buy an alternative brand (Warrington \& Shim, 2000).

Linking brand commitment and positive WOM has been scrutinized in previous studies. Some previous studies exhibited that brand commitment was an antecedent of positive WOM and had positively influenced positive WOM (Albert et al., 2013; Albert \& Merunka, 2013; Tuškej et al., 2013). In line with the previous study, we expected that brand commitment can also be a predictor of positive WOM. Therefore, we recommend the following hypothesis:

H6: Brand commitment is positively connected to positive WOM.

Based on the purpose of the current research, literature review, and hypotheses development, Figure 1 displayed the recommended research model.

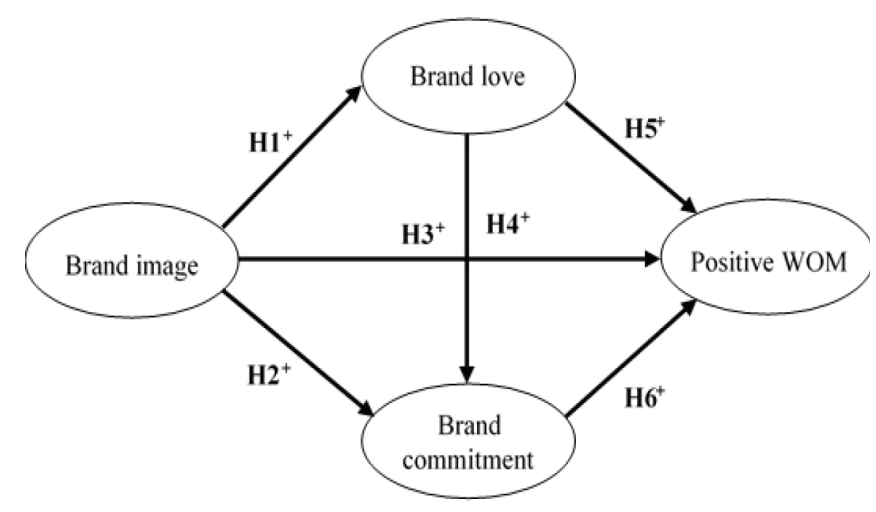

Figure 1: The proposed research model 


\section{Research Methodology}

\subsection{Measures}

The measurement items of the constructs from prior studies were reviewed and modified to suit the research environment. We employed a five-point Likert scale to measure the indicators. In the current investigation, we modified four items of brand image from Lien et al. (2015), four items of brand love from Carroll and Ahuvia (2006), five items of brand commitment from (Bridson et al., 2008; Maisam \& Mahsa, 2016) and five indicators of positive WOM from (Bridson et al., 2008).

\subsection{Sample and Data Collection}

The data was collected to investigate clients at electronic stores in Ho Chi Minh City, Vietnam. The convenience sampling of this research sample was conducted with different groups of clients over gender and age in Ho Chi Minh City, Vietnam. We gave a sum of 350 questionnaires; 315 questionnaires were returned, and 48 questionnaires were dismissed, as there was not enough information. There were 267 questionnaires employed for the final study. The sample consisted of 126 male customers $(47.2 \%)$ and 141 female customers $(52.8 \%)$. Clients in the age group 18 to 25 made $24.7 \%$ of the respondents, $41.9 \%$ were in the age group 26 to $35,12 \%$, in the age group 36 to 45 , and $13.9 \%$ were older than 45 .

\subsection{Analytical Method}

The partial least squared (PLS) method was applied in this research as this method had the most important reasons for using this method are: (1) nonnormal data, (2) small sample sizes, and (3) formatively measured constructs (Hair et al., 2014). PLS method was employed for examining the recommended research model and hypotheses. Testing the recommended research model and suggestions were conducted through two steps: (1) Assessment of the measurement model and (2) Assessment of the structural model (Hair et al., 2017).

\section{Results and Discussion}

\subsection{Results}

\subsubsection{Evaluation of the Measurement Model: Construct Reliability and Validity}

Table 1 exhibits the measurement scale of the construct's study results. We used Cronbach's alpha and composite reliability (C.R.) for estimating the reliability of the research.
Cronbach's alpha $(\alpha)$ values of the constructs should be greater than 0.70 , and the C.R. values greater than 0.70 , which implies that there is adequate internal consistency among the constructs (Hair et al., 2017). Table 1 demonstrates that Cronbach's alpha values of the independent variables were above 0.70 . Consequently, these constructs have internal consistency reliability.

We implemented the factor loading of all items values and the average variance extracted (AVE) to estimate convergent validity. The factor loading and AVE should be larger than 0.50 (Bagozzi \& Yi, 1988; Hair et al., 2017). In this current study, the factor loading of all items and the AVE values were over 0.50 . Therefore, the convergent validity of the constructs was suitable.

Moreover, we estimated discriminant validity through the Fornell-Larcker standard (Fornell \& Larcker, 1981). It represented the square root of the AVE values with the latent variable. Precisely, the square root of the AVE should be more potent than its most potent correlation with any other construct (Hair et al., 2017). Table 2 reveals that the square root of AVE is reflective of construct brand image, brand love, brand commitment; and positive WOM was more potent than the corresponding latent variables correlation. Therefore, the discriminant validity of these constructs was approved.

\subsubsection{Evaluation of the Structural Model and Hypotheses Testing}

\section{Evaluation of the model fit}

Table 3 displays the model fit findings. The outcomes in Table 3 illustrated that the Chi-square $=418.003$ was meaningful at the 0.05 level $(p=0.00)$. SRMR (standardized root mean square residual) measured the estimated model fit of the suggested research model. By custom, a model had a suitable model fit when SRMR was smaller than $0.08(\mathrm{Hu}$ $\&$ Bentler, 1998). The report results in Table 3 revealed that this model had an SRMR index $=0.062<0.08$. Therefore, the recommended research model was suitable for the study data. Moreover, checking of a multicollinearity matter stated that all VIF values were under the threshold of 5. Thus, there was no multicollinearity matter in the structural model (Hair et al., 2017).

\section{Hypotheses testing}

Table 4 exposes the outcomes of hypothesis testing. Bootstrapping results (with 5000 re-samplings) for the relationship between the concepts in the proposed study model explained that the t-value of the H1, H2, H3, H4, H5, H6 was greater than 1.96, and these hypotheses were significant at the $5 \%$ level. Therefore, these hypotheses were confirmed. 
Table 1: Measurement items of the construct's analysis outcomes

\begin{tabular}{|c|c|c|c|c|}
\hline Constructs and measurement items & $\begin{array}{l}\text { Factor } \\
\text { loading }\end{array}$ & $\alpha$ & CR & AVE \\
\hline Brand image & & 0.850 & 0.898 & 0.688 \\
\hline 1. This electronic store brand is reliable. & 0.818 & & & \\
\hline 2. This electronic store brand is attractive. & 0.821 & & & \\
\hline 3. This electronic store brand is pleasing. & 0.842 & & & \\
\hline 4. This electronic store brand has a good reputation. & 0.837 & & & \\
\hline Brand love & & 0.758 & 0.846 & 0.580 \\
\hline 1. This electronic store brand is awesome & 0.764 & & & \\
\hline 2. This electronic store brand makes me feel good. & 0.798 & & & \\
\hline 3. I love this electronic store brand. & 0.754 & & & \\
\hline 4. I am passionate about this electronic store brand & 0.728 & & & \\
\hline Brand commitment & & 0.870 & 0.906 & 0.659 \\
\hline 1. I want a long-term connection with this electronic store brand. & 0.815 & & & \\
\hline 2. If the electronic store brand disappointed me once or twice, I wouldn't mind. & 0.824 & & & \\
\hline 3. Despite rivals' offers, I always shop at this electronic store brand. & 0.786 & & & \\
\hline $\begin{array}{l}\text { 4. Even if another electronic store brand had a sale, I would still buy from this } \\
\text { electronic store brand }\end{array}$ & 0.835 & & & \\
\hline 5. I feel personally satisfied when I buy this electronic store brand. & 0.796 & & & \\
\hline Positive WOM & & 0.816 & 0.872 & 0.576 \\
\hline 1. I say positive things about this electronic store brand to other people. & 0.746 & & & \\
\hline 2. I encourage others to do business with this electronic store brand. & 0.732 & & & \\
\hline $\begin{array}{l}\text { 3. I would recommend this electronic store brand to someone who seeks my } \\
\text { advice. }\end{array}$ & 0.758 & & & \\
\hline $\begin{array}{l}\text { 4. I often find myself telling people about the positive experiences I have had } \\
\text { with this electronic store brand. }\end{array}$ & 0.792 & & & \\
\hline $\begin{array}{l}\text { 5. Because of my experiences with this electronic store brand, I try to persuade } \\
\text { friends, family, and colleagues to switch to this electronic store brand. }\end{array}$ & 0.767 & & & \\
\hline
\end{tabular}

Table 2: Discriminant validity result

\begin{tabular}{|l|c|c|c|c|}
\hline & $\begin{array}{c}\text { Brand } \\
\text { commitment }\end{array}$ & $\begin{array}{c}\text { Brand } \\
\text { image }\end{array}$ & $\begin{array}{c}\text { Brand } \\
\text { love }\end{array}$ & $\begin{array}{c}\text { Positive } \\
\text { WOM }\end{array}$ \\
\hline $\begin{array}{l}\text { Brand } \\
\text { commitment }\end{array}$ & 0.811 & & & \\
\hline Brand image & 0.573 & 0.830 & & \\
\hline Brand love & 0.690 & 0.611 & 0.761 & \\
\hline $\begin{array}{l}\text { Positive } \\
\text { WOM }\end{array}$ & 0.708 & 0.682 & 0.738 & 0.759 \\
\hline
\end{tabular}

Table 3: Model fit results

\begin{tabular}{|l|c|}
\hline & Saturated model \\
\hline SRMR & 0.062 \\
\hline d_ULS & 0.667 \\
\hline d_G1 & 0.313 \\
\hline d_G2 & 0.275 \\
\hline Chi-square & 418.003 \\
\hline NFI & 0.834 \\
\hline
\end{tabular}


Table 4: The outcomes of hypothesis testing

\begin{tabular}{|l|c|c|c|c|c|}
\hline Relationship & Hypotheses & $\begin{array}{c}\text { Path } \\
\text { coefficients }\end{array}$ & t-value & p-value & Results \\
\hline Brand image $\rightarrow$ Brand love & H1 & 0.611 & 10.174 & 0.000 & supported \\
\hline Brand image $\rightarrow$ Brand commitment & $\mathrm{H} 2$ & 0.573 & 3.972 & 0.000 & supported \\
\hline Brand image $\rightarrow$ Positive WOM & $\mathrm{H} 3$ & 0.682 & 5.557 & 0.000 & supported \\
\hline Brand love $\rightarrow$ Brand commitment & $\mathrm{H} 4$ & 0.542 & 8.404 & 0.000 & supported \\
\hline Brand love $\rightarrow$ Positive WOM & $\mathrm{H} 5$ & 0.513 & 6.057 & 0.00 & Supported \\
\hline Brand commitment $\rightarrow$ Positive WOM & $\mathrm{H} 6$ & 0.292 & 4.956 & 0.000 & supported \\
\hline
\end{tabular}

Table 5: $R^{2}, f^{2}$, and $Q^{2}$ results

\begin{tabular}{|c|c|c|c|c|c|}
\hline Relationship & $\begin{array}{c}\text { Path } \\
\text { coefficients }\end{array}$ & $f^{2}$ & Construct & $\mathbf{R}^{2}$ & $\mathbf{Q}^{2}$ \\
\hline Brand image $\rightarrow$ Brand love & 0.611 & 0.597 & \multirow{2}{*}{ Brand love } & \multirow{2}{*}{0.374} & \multirow{2}{*}{0.196} \\
\hline Brand image $\rightarrow$ Brand commitment & 0.573 & 0.075 & & & \\
\hline Brand image $\rightarrow$ Positive WOM & 0.682 & 0.157 & \multirow{2}{*}{$\begin{array}{c}\text { Brand } \\
\text { commitment }\end{array}$} & \multirow{2}{*}{0.512} & \multirow{2}{*}{0.312} \\
\hline Brand love $\rightarrow$ Brand commitment & 0.542 & 0.377 & & & \\
\hline Brand love $\rightarrow$ Positive WOM & 0.513 & 0.174 & \multirow{2}{*}{ Positive WOM } & \multirow{2}{*}{0.672} & \multirow{2}{*}{0.354} \\
\hline Brand commitment $\rightarrow$ Positive WOM & 0.292 & 0.127 & & & \\
\hline
\end{tabular}

\section{$R^{2}$ (explained variance), $f^{2}$ (effect size) and $Q^{2}$ (predictive relevance)}

The structural model is analyzed with the principal evaluation metrics $\mathrm{R}^{2}$ (explained variance), $\mathrm{f}^{2}$ (effect size), and $\mathrm{Q}^{2}$ (predictive relevance) (Hair et al., 2017). The coefficient of determination $\left(\mathrm{R}^{2}\right)$ was the overall impact size measure for the structural model (Garson, 2016). The $\mathrm{R}^{2}$ value is between 0 to 1 , with more massive levels which meant more precision in predictions. The $\mathrm{R}^{2}$ value of $0.19,0.33$, and 0.67 could be manifested as weak, moderate, and substantial (Chin, 1998). The ( $\left.\mathrm{f}^{2}\right)$ effect size allowed assessing the independent variable contribution to the dependent variable. The $\mathrm{f}^{2}$ value 0.02 was small, 0.15 was medium, and 0.35 was high (Cohen, 1988). The $\mathrm{Q}^{2}$ value evaluated the structural model's predictive relevance for each endogenous construct. The $\mathrm{Q}^{2}$ value should be larger zero (Hair et al., 2017).

In this current research, the $\mathrm{R}^{2}$ value for the overall model was 0.672 (see Table 5), equal 0.67 , which is considered as a substantial influence; we remarked that brand image had the most decisive impact (0.682), followed by brand love (0.513), followed by brand commitment (0.292). Besides, brand image and brand love explained $51.2 \%$ of the variance on brand commitment; we also showed that brand image had a higher impact (0.573) than brand love (0.542). Moreover, the brand image explained $37,4 \%$ brand love, and it had a reasonably strong effect $(0.611)$.

Table 5 explains the $\mathrm{f}^{2}$ effect sizes. The high $\mathrm{f}^{2}$ effect size occurred for the link of brand image $\rightarrow$ brand love (0.597), and brand love $\rightarrow$ brand commitment (0.377). The medium $\mathrm{f}^{2}$ effect size appeared for the association of brand love $\rightarrow$ positive WOM (0.174), and brand image $\rightarrow$ positive WOM (0.157). The small $\mathrm{f}^{2}$ effect size happened for the connection brand image $\rightarrow$ brand commitment (0.075).

Table 5 also reveals that the $\mathrm{Q}^{2}$ values of three endogenous variables were above zero. Accurately, brand love had $\mathrm{Q}^{2}$ values (0.196); brand commitment had $\mathrm{Q}^{2}$ values $(0.312)$, and positive WOM had $\mathrm{Q}^{2}$ index (0.354). These outcomes reinforced the model's predictive strength as a fit for the endogenous latent variables.

\subsection{Discussion}

This current study's contribution was to test and measure the effect of brand image, brand love on brand commitment, and positive WOM in the various contexts from prior research. Most of the previous studies concentrated on these effects for the different fields, and the current research displayed these effects in the Vietnam electronic store market. 
The current research outcomes reveal that the six hypotheses in the proposed study model were approved. The research results illustrate that brand image had a positive influence on brand love. The brand image was a precursor to brand love. The $\mathrm{f}^{2}$ effect size of the connection between brand image and brand love was large $(0.597)$. The previous empirical research confirmed this research (Islam \& Rahman, 2016; Ismail \& Spinelli, 2012; Unal \& Aydın, 2013). The research findings also explain that brand image was positively related to brand commitment. The brand image was an antecedent of brand commitment; yet, the $\mathrm{f}^{2}$ influence size of the bond between brand image and brand commitment was small (0.075). The previous empirical investigations verified this research (Seo \& Park, 2018; Tu et al., 2013). The study findings also indicate that brand image had a significant positive impact on positive WOM. The brand image was a predictor of positive WOM. The $\mathrm{f}^{2}$ effect size of the relationship between brand image and positive WOM was medium (0.157). The previous empirical studies proved this research (Anggraeni \& Rachmanita, 2015; Permana \& Ilham, 2018).

Likewise, the research results also prove that brand love was positively linked to brand commitment. Brand love was a predecessor of brand commitment, and the $\mathrm{f}^{2}$ effect size of the relationship of brand love and brand commitment was large (0.377). The previous empirical study confirmed the results of this research (Albert \& Merunka, 2013). Besides, the research results also indicate that brand love was positively related to positive WOM. Brand love was an antecedent of positive WOM, and the $\mathrm{f}^{2}$ effect size of the connection of brand love and positive WOM was moderate (0.174). The previous empirical studies confirmed this research (Bairrada et al., 2019; Hsu \& Chen, 2018).

Furthermore, the findings of the study also confirm that brand commitment had a positive influence on positive WOM. The brand commitment was an antecedent of positive WOM, and the effect size of the relationship of brand commitment and positive WOM was medium-weak $(0.127)$. The $\mathrm{f}^{2}$ previous empirical research supported this research (Albert et al., 2013; Albert \& Merunka, 2013; Tuškej et al., 2013).

\section{Conclusions and Limitations}

In line with the previous studies, this research examined the effect of brand image, brand love on brand commitment, and positive WOM. Therefore, managers should give marketing plans that improve the customer's perception of brand image, brand love to enhancing brand commitment and positive WOM. This study guides managers to identify the importance of brand image on brand love, brand commitment, and positive WOM. Hence, managers should build marketing programs to improve the brand image (such as advertising through social media, promotion activities, etc., and other marketing means). If customers have a positive brand image, customers will continue to have a positive tendency on brand love, brand commitment, and positive WOM. Besides, the research will help practitioners recognize the influence of brand love on brand commitment and positive WOM. So, managers should create marketing plans to develop the brand love. When clients' brand love increases, clients will increase brand commitment and positive WOM. Finally, the study will enable practitioners to verify the impact of brand commitment on positive WOM. Consequently, managers should create marketing strategies to enhance brand commitment, which points to improving positive WOM.

This study has some limitations, and it gives some directions for future studies. First, the research may not be generalizable to all other disciplines; therefore, future studies should be replicated in different fields such as e-commerce websites, watches, etc. Second, this study only tested the effect of brand image, brand love on brand commitment, and positive WOM; hence, future investigations should concentrate on other constructs such as brand trust, brand personality, etc.

\section{References}

Aaker, D. A. (1996). Building Strong Brand. New York, NY: Free Press.

Albert, N., \& Merunka, D. (2013). The role of brand love in consumer-brand relationships. Journal of Consumer Marketing, $30,258-266$.

Albert, N., Merunka, D., \& Valette-Florence, P. (2013). Brand passion: Antecedents and consequences. Journal of Business Research, 66(7), 904-909.

Anggraeni, A., \& Rachmanita. (2015). Effects of Brand Love, Personality and Image on Word of Mouth: The Case of Local Fashion Brands Among Young Consumers. Procedia - Social and Behavioral Sciences, 211(215), 442-447.

Armelini, G. (2011). The Effect of Word of Mouth in Customer Equity and Brand Equity. Chinese Business Review, 10(03), 205-216.

Arndt, J. (1967). Word-of-mouth advertising and informal communication. In D. Cox (Ed.), Risk taking and information handing in consumer behaviour. Boston, MA: Harvard University Press.

Assael, H. (1988). Consumer behavior and marketing action (6th ed.). Cincinnati, Ohio: South-Western College Publishing.

Bairrada, C. M., Coelho, A., \& Lizanets, V. (2019). The impact of brand personality on consumer behavior: The role of brand love. Journal of Fashion Marketing and Management, 23(1), $30-47$.

Bone, P. F. (1995). Word-of-Mouth Effects on Short-term Longterm Product Judgments. Journal of Business Research, 32(3), 213-223. 
Bridson, K., Evans, J., \& Hickman, M. (2008). Assessing the relationship between loyalty program attributes, store satisfaction and store loyalty. Journal of Retailing and Consumer Services, 15(5), 364-374.

Carroll, B. A., \& Ahuvia, A. C. (2006). Some antecedents and outcomes of brand love. Marketing Letters, 17(2), 79-89.

Chaudhuri, A., \& Holbrook, M. B. (2001). The Chain of Effects from Brand Trust and Brand Affect to Brand Performance: The Role of Brand Loyalty. Journal of Marketing, 65(2), 81-93.

Chin, W. W. (1998). The partial least squares approach to structural equation modeling. In G. A. Macoulides (Ed.), Modern Methods for Business Research (pp. 295-336). Mahwah, NJ: Lawrence Erlbaum Associates.

Cho, E., Fiore, A. M., \& Russell, D. W. (2010). Validation of a Fashion Brand Image Scale Capturing Cognitive, Sensory, and Affective Associations: Testing Its Role in an Extended Brand Equity Model. Psychology \& Marketing, 32(1), 28-48.

Cohen, J. (1988). Statistical power analysis for the behavioral sciences. Mahwah, NJ: Lawrence Erlbaum Associates.

Coulter, R. A., Price, L. L., \& Feick, L. (2003). Rethinking the Origins of Involvement and Brand Commitment: Insights from Postsocialist Central Europe. Journal of Consumer Research, 30(2), 151-169.

Dick, A. S., \& Basu, K. (1994). Customer loyalty: Toward an integrated conceptual framework. Journal of the Academy of Marketing Science, 22(2), 99-113.

Dobni, D., \& Zinkhan, G. M. (1990). In search of brand image: A foundation analysis. Advances in Consumer Research, 17, $110-119$.

East, R., Hammond, K., \& Lomax, W. (2008). Measuring the impact of positive and negative word of mouth on brand purchase probability. International Journal of Research in Marketing, 25(3), 215-224.

Ferreira, P., Rodrigues, P., \& Rodrigues, P. (2019). Brand Love as Mediator of the Brand Experience Satisfaction: Loyalty Relationship in a Retail Fashion Brand. Management and Marketing, 14(3), 278-291.

File, K. M., \& Prince, R. A. (1991). Positive Word of Mouth: Customer Satisfaction and Buyer Behavior. International Journal of Bank Marketing, 10(1), 25-29.

Fournier, S. (1998). Consumers and Their Brands: Developing Relationship Theory in Consumer Research. Journal of Consumer Research, 24(4), 343-353.

Garson, G. D. (2016). Partial least squares: Regression \& structural equation models (2016 ed). Asheboro, NC: Statistical Associates Publishers.

Hair, J. F., Hult, G. T. M., Ringle, C. M., \& Sarstedt, M. (2017). A Primer on Partial Least Squares Structural Equation Modeling (PLS-SEM) (2nd ed.). Los Angeles, CA: Sage Publications, Inc.

Hair, J. F., Sarstedt, M., Hopkins, L., \& Kuppelwieser, V. G. (2014). Partial least squares structural equation modeling (PLS-SEM):
An emerging tool in business research. European Business Review, 26(2), 106-121.

Hennig-Thurau, T., Gwinner, K. P., Walsh, G., \& Gremler, D. D. (2004). Electronic word-of-mouth via consumer-opinion platforms: What motivates consumers to articulate themselves on the Internet? Journal of Interactive Marketing, 18(1), 38-52.

Hsieh, S. W., Lu, C. C., \& Lu, Y. H. (2018). A Study on the Relationship Among Brand Image, Service Quality, Customer Satisfaction, and Customer Loyalty: Taking 'the Bao Wei Zhen Catering Team' As an Empirical Study. KnE Social Sciences, $3(10), 1768-1781$.

Hsu, C. L., \& Chen, M. C. (2018). How gamification marketing activities motivate desirable consumer behaviors: Focusing on the role of brand love. Computers in Human Behavior, 88(March), 121-133.

Islam, J. U., \& Rahman, Z. (2016). Examining the effects of brand love and brand image on customer engagement: An empirical study of fashion apparel brands. Journal of Global Fashion Marketing, 7(1), 45-59.

Ismail, A. R., \& Spinelli, G. (2012). Effects of brand love, personality and image on word of mouth: The case of fashion brands among young consumers. Journal of Fashion Marketing and Management: An International Journal, 16(4), 386-398.

Kapferer, J. N. (1997). Strategic Brand Management: Creating and Sustaining Brand Equity Long Term (2nd ed.). London, UK: Kogan Page Limited.

Karjaluoto, H., Munnukka, J., \& Kiuru, K. (2016). Brand love and positive word of mouth: The moderating effects of experience and price. Journal of Product and Brand Management, 25(6), 527-537.

Kazemi, A., PaEmami, V. M., Abbaszadeh, A., \& Pourzamani, J. (2013). Impact of Brand Identity on Customer Loyalty and Word of Mouth Communications, Considering Mediating Role of Customer Satisfaction and Brand Commitment. (Case Study: Customers of Mellat Bank in Kermanshah). International Journal of Academic Research in Economics and Management Sciences, 2(4), 1-14.

Keller, K. L. (1993). Conceptualizing, Measuring, and Managing Customer-Based Brand Equity. Journal of Marketing, 57, 1-22.

Khraim, H. S. (2011). The willingness to generate positive word of mouth marketing: The case of students in private universities in Jordan. Pertanika Journal of Social Science and Humanities, 19(2), 273-289.

Lastovicka, J. L., \& Gardner, D. M. (1979). Components of Involvement. In J. C. Maloney \& B. Silverman (Eds.), Attitude research plays for high stakes (pp. 53-73). Chicago, IL: American Marketing Association.

Lee, C., \& Lim, S. Y. (2020). Impact of Environmental Concern on Image of Internal GSCM Practices and Consumer Purchasing Behavior. Journal of Asian Finance, Economics and Business, 7(6), 241-254. https://doi.org/10.13106/ jafeb.2020.vol7.no6 
Maisam, S., \& Mahsa, R. D. (2016). Positive Word of Mouth Marketing: Explaining the Roles of Value Congruity and Brand Love. Journal of Competitiveness, 8(1), 19-37.

Özdemir, A., Tozlu, E., Şen, E., \& Ateşoğlu, H. (2016). Analyses of Word-of-mouth Communication and its Effect on Students> University Preferences. Procedia - Social and Behavioral Sciences, 235(October), 22-35.

Park, C., Jaworski, B., \& Maclnnis, D. (1986). Strategic Brand Concept-Image Management. Journal of Marketing, 50(4), 135-145.

Park, H., \& Park, S. (2019). The effect of emotional image on customer attitude. Journal of Asian Finance, Economics and Business, 6(3), 259-268. https://doi.org/10.13106/jafeb.2019. vol6.no3.259

Permana, R., \& Ilham, F. (2018). Antecedents and Consequences of Brand Image: A Case of a Packaged Drinking Water Product. KnE Social Sciences, 3(10), 209-219.

Ranjbarian, B., Kazemi, A., \& Borandegi, F. (2013). Analyzing the Antecedents and Consequences of Brand Love with a Case Study on Apple Cell phone Users. International Journal of Academic Research in Business and Social Sciences, 3(11), 320-329.

Sallam, M. A. (2014). The Effects of Brand Image and Brand Identification on Brand Love and Purchase Decision Making: The Role of WOM. International Business Research, 7(10), 187-193.

Seo, E. J., \& Park, J. W. (2018). A study on the effects of social media marketing activities on brand equity and customer response in the airline industry. Journal of Air Transport Management, 66(August 2017), 36-41.

Sondoh Jr, S. L., Omar, M. W., Wahid, N. A., Ismail, I., \& Harun, A. (2007). The effect of brand image on overall satisfaction and loyalty intention in the context of color cosmetic. Asian Academy of Management, 12(1), 83-107.

Sousa, A., Nobre, H., \& Farhangmehr, M. (2019). Cosmopolitanism and the mediating effect of country image on consumers' purchase, visit and investment intentions. Journal of Asian Finance, Economics and Business, 6(4), 159-170. https://doi. org/10.13106/jafeb.2019.vol6.no4.159

Srivastava, D., \& Sharma, R. W. (2017). Developing a Model for Studying the Antecedents and Effects of Word of Mouth (WoM) and e-WoM Marketing Based on Literature Review. Jindal Journal of Business Research, 6(1), 25-43.

Stokes, D., \& Lomax, W. (2002). Taking control of word of mouth marketing: The case of an entrepreneurial hotelier. Journal of Small Business and Enterprise Development, 9(4), 349-357.

Traylor, M. B. (1981). Product Involvement and Brand Commitment. Journal of Advertising Research, 21(6), 51-56.

Tu, Y. T., Lin, S. Y., \& Hsu, T. K. (2013). The Impact of Brand Image and Customer Commitment on Loyalty: An Empirical Study of Automobile Sector. Information Management and Business Review, 5(4), 181-193.

Tuškej, U., Golob, U., \& Podnar, K. (2013). The role of consumerbrand identification in building brand relationships. Journal of Business Research, 66(1), 53-59.

Unal, S., \& Aydın, H. (2013). An Investigation on the Evaluation of the Factors Affecting Brand Love. Procedia - Social and Behavioral Sciences, 92(2013), 76-85.

Warrington, P., \& Shim, S. (2000). An empirical investigation of the relationship between product involvement and brand commitment. Psychology and Marketing, 17(9), 761-782. 